\title{
Molasses Distillery Slops Supply Nitrogen and Potassium Fertilizer to Flooded Rice ${ }^{1,2}$
}

\author{
José Vicente-Chandler, Fernando Abruña and José Lozano 3
}

\begin{abstract}
Yields of four consecutive rice crops that received $\mathrm{P}$ fertilizer only increased with each increment of rum distillery slops, from an average of $2,033 \mathrm{~kg}$ of rough rice/ha when no slops were applied to $5,905 \mathrm{~kg} / \mathrm{ha}$ when $240 \mathrm{hl}$ of slops were applied/ha weekly for 12 weeks starting 2 weeks after planting. At this level of slops, a total of $215 \mathrm{~kg}$ of $\mathrm{N}$ and $475 \mathrm{~kg}$ of $\mathrm{K}$ were applied to each rice crop. Applying fertilizer $\mathrm{N}$ in addition to $160 \mathrm{hl}$ of slops/ha weekly did not increase yields. Leaf contents of $\mathrm{N}, \mathrm{P}, \mathrm{K}, \mathrm{Ca}$, and $\mathrm{Mg}$ were not affected by the level of slops applied. Soil pH decreased with increasing levels of distillery slops. Exchangeable $\mathrm{NH}_{3}$ content of the soil was not affected by the application of slops. Exchangeable and $\mathrm{HNO}_{3}$-extractable $\mathrm{K}$ increased with increasing levels of slops, from a total of $313 \mathrm{~kg} / \mathrm{ha}$ when no slops were applied to 699 $\mathrm{kg} / \mathrm{ha}$ when $240 \mathrm{hl}$ of slops were applied/ha weekly for 12 weeks to four successive rice crops.
\end{abstract}

\section{INTRODUCTION}

About 1.6 billion liters of rum distillery slops is produced yearly in Puerto Rico, constituting a major disposal problem for the rum industry. The largest rum producer on the Island has spent $\$ 15$ million on a treatment plant for slops. Slops from molasses vary considerably in composition, averaging about $10 \%$ dry matter, which consists of the following range in composition percentages $\mathrm{N}=1-2 \%, \mathrm{~K}=2-4 \%, \mathrm{Mg}=$ $1-3 \%, \mathrm{Ca}=2-3 \%, \mathrm{P}=.03-.06 \%$ and organic matter $=91 \%$.

Rosado and González (5) recently reviewed the literature on the use of slops as fertilizer. Innes (2) found that applying slops to sugarcane increased yields of sugar. Takata (7) found that diluted distillery slops were not harmful to rice plants and, at proper levels, increased yields. Pérez-Escolar and Lugo-López (4) found that slops increased yields of cut grasses. However, the use of slops as fertilizer is limited by the high cost of drying or transporting.

Puerto Rico is developing a modern rice industry on about 16,000 acres on the north coast, from San Juan, where the largest rum distillery on the island is located, to Arecibo, where the second largest distillery is established. Together, these distilleries produce about 1.2 billion liters of slops yearly.

${ }^{1}$ Manuscript submitted to Editorial Board October 5, 1983.

${ }^{2}$ This paper covers work carried out cooperatively between the Agricultural Research Service, USDA; and the Agricultural Experiment Station, College of Agricultural Sciences, Mayagüez Campus, University of Puerto Rico.

${ }^{3}$ Soil Scientists, ARS-USDA, and Research Assistant, Agricultural Experiment Station, College of Agricultural Sciences, Mayagüez Campus, University of Puerto Rico, respectively. 
If slops are found to be an efficient source of $\mathrm{N}$ and $\mathrm{K}$ for rice, distribution in the field should be relatively simple. Slops could be pumped from the distilleries located at both extremes of the north coast rice growing area and injected into the main irrigation canals of each plain at the dosage found to be most desirable. From there, they would be distributed in the rice fields at no extra cost.

In a preliminary study, the authors found that applying 1,100 or 2,200 $\mathrm{hl}$ of slops/ha 3 weeks after planting increased rice yields by an average of 35 percent over those produced by nonfertilized rice and that dividing the $2,200 / \mathrm{hl}$ level into three equal biweekly applications increased yields by an additional $45 \%$.

The experiments discussed in this paper were conducted to determine the effect of applying four levels of slops and of supplementary $\mathrm{N}$ applications, on yields of intensively managed rice for four successive crops over a 2-year period (1981-82) and on soil condition at the end of that period.

\section{MATERIALS AND METHODS}

The experiment was carried out at the Gurabo Substation at an elevation of about $80 \mathrm{~m}$. Minimum and maximum temperatures are 19 and $31^{\circ} \mathrm{C}$, respectively. Average annual rainfall is $1,450 \mathrm{~mm}$. The soil is Coloso clay (Aeric Tropic Fluvaquent) with a pH of 7.0.

Plots were $3 \times 3 \mathrm{~m}$ and were surrounded by earthen dikes. Each plot was connected directly by pipes to ditches so that it could be flooded or drained individually. A good seedbed was prepared, and $30 \mathrm{~kg} / \mathrm{ha}$ of $\mathrm{P}$ was disced in. Seed of the Brazos, Nortai, or Mars varieties, as indicated, were planted at the rate of $120 \mathrm{~kg} / \mathrm{ha}$ and covered lightly with soil. The plots were then irrigated by flooding them periodically as required. For weed control, Propanil was applied 3 weeks after planting. Then the plots were kept flooded to a depth of about $10 \mathrm{~cm}$ until 2 weeks before harvesting. Insects and diseases were controlled by spraying with appropriate pesticides as required. The rice was harvested when it contained about $20 \%$ moisture. Then it was cleaned and dried to $12 \%$ moisture.

At the preblooming stage of the third crop, samples of the third leaves were dried and analyzed for $\mathrm{N}$ by the Macro-Kjeldahl method; for $\mathrm{K}$, by flame photometry; for $\mathrm{P}$, by colorimetry; for $\mathrm{Mn}$, by oxidation with potassium periodate; and for $\mathrm{Ca}$ and $\mathrm{Mg}$, by the Versenate method.

After the experiment was concluded, the soil in all plots was sampled by taking 10 borings from 0 - to $15-\mathrm{cm}$ depths in each plot. The samples were air dried and passed through a 10-mesh screen. Exchangeable bases were extracted with normal neutral ammonium acetate, and exchangeable. $\mathrm{Ca}$ and $\mathrm{Mg}$ were determined by the Versenate titration method (1). 
Exchangeable $\mathrm{K}$ was determined by flame photometry and readily available $\mathrm{K}$ by extraction with $\mathrm{HNO}_{3}$. Exchangeable $\mathrm{Al}$ was extracted with normal $\mathrm{KCl}$ and determined by the double titration method (3). Soil reaction was measured with a glass electrode $\mathrm{pH}$ meter by the use of a saturated paste.

After four crops were grown, all plots were planted to rice without further applications of fertilizer or slops in order to determine the residual effects of the treatments on rice yields.

Treatments, replicated six times in a partially balanced block design, were as follows:

1. No Nor K

2. $60 \mathrm{~kg} / \mathrm{ha}$ each of $\mathrm{N}$ and $\mathrm{K}$ applied at planting and 45 days later

3. $80 \mathrm{hl}$ of distillery slops/ha weekly for 12 weeks starting 2 weeks after planting

4. $160 \mathrm{hl}$ distillery slops/ha weekly

5. $240 \mathrm{hl}$ of distillery slops/ha weekly

6. $160 \mathrm{hl}$ of slops/ha weekly $+60 \mathrm{~kg}$ of $\mathrm{N} / \mathrm{ha}$

7. $160 \mathrm{hl}$ of slops/ha weekly $+120 \mathrm{~kg}$ of $\mathrm{N} / \mathrm{ha}$

8. $160 \mathrm{hl}$ of slops/ha weekly $+240 \mathrm{~kg}$ of $\mathrm{N} / \mathrm{ha}$

\section{RESULTS AND DISCUSSION}

Yields from plots that received $\mathrm{P}$ only, increased with each increment in the levels of slops applied, from an average of $3,033 \mathrm{~kg}$ of rough rice/ ha when no slops were applied to $5,905 \mathrm{~kg} / \mathrm{ha}$, a very high yield, when $240 \mathrm{hl}$ slops were applied/ha weekly for 12 weeks, starting 2 weeks after planting (table 1).

Yields increased linearly with each increment in the level of slops applied (fig. 1). Considerably higher yields were produced during the dry season than during the wet season due to higher insolation rates during the dry season.

Applying fertilizer $\mathrm{N}$ in addition to $160 \mathrm{hl}$ of slops weekly did not significantly increase yields above those obtained with the application of $240 \mathrm{hl}$ of slops/ha weekly (table 1).

The leaf content of $\mathrm{N}, \mathrm{P}, \mathrm{K}, \mathrm{Ca}$, and $\mathrm{Mg}$ at the prebloom stage were not affected by the treatments (table 2).

Soil pH decreased as the level of slops applied increased, from 7.15 when no slops were applied to 6.3 when $240 \mathrm{hl}$ was applied weekly. Increasing $\mathrm{N}$ rates also tended to decrease soil $\mathrm{pH}$.

Exchangeable $\mathrm{NH}_{3}$ in the soil was not affected by the treatments, indicating that the $\mathrm{N}$ applied was (a) taken up by the rice plants, (b) was lost through leaching or by volatilization, or (c) was not mineralized from organic form in the slops. Exchangeable $\mathrm{Ca}$ and $\mathrm{Mg}$ content of the soil was not appreciably affected by the level of slops or of $\mathrm{N}$ applied. 
TABLE 1.-Effect of rum distillery slops and of fertilizer nitrogen on yields produced by four successive rice crops and a residual crop

No $\mathrm{N}, \mathrm{K}$ or slops

$60 \mathrm{~kg}$ of $\mathrm{N}$ and $\mathrm{K} / \mathrm{ha}$ at planting and 45 days later

$80 \mathrm{hl}$ of slops/ha weekly ${ }^{3}$

$160 \mathrm{hl}$ of slops/ha weekly

$240 \mathrm{hl}$ of slops/ha weekly

Yields of dry rough rice $(\mathrm{kg} / \mathrm{ha})$

$160 \mathrm{hl}$ of slops/ha weekly $+60 \mathrm{~kg}$ of $\mathrm{N} / \mathrm{ha}^{4}$

$160 \mathrm{hl}$ of slops/ha weekly $+120 \mathrm{~kg}$ of $\mathrm{N} / \mathrm{ha}$

$160 \mathrm{hl}$ of slops/ha weekly $+240 \mathrm{~kg}$ of $\mathrm{N} / \mathrm{ha}$

\footnotetext{
${ }^{1}$ Received no fertilizer or slops.

${ }^{2}$ Values followed by the same letters do not differ significantly at the $5 \%$ level.

${ }^{3}$ For 12 weeks, starting 2 weeks after planting.

${ }^{4}$ All $\mathrm{N}$ applied in two equal applications, one at planting and one 6 weeks later.
}

\begin{tabular}{cc} 
& \multicolumn{1}{c}{$\begin{array}{c}\text { Residual } \\
\text { crop }\end{array}$} \\
\cline { 2 - 2 } verage of & \multicolumn{1}{c}{$\begin{array}{c}\mathrm{V} \\
\text { Mars variety } \\
\text { planted } \\
3 / 21 / 83\end{array}$} \\
\hline $3,033 \mathrm{~d}^{2}$ & $3,070 \mathrm{c}, \mathrm{d}$ \\
$4,750 \mathrm{~b}$ & $2,640 \mathrm{~d}$ \\
& $3,480 \mathrm{~b}, \mathrm{c}$ \\
$3,953 \mathrm{c}$ & $3,790 \mathrm{a}, \mathrm{b}$ \\
$4,873 \mathrm{~b}$ & $4,560 \mathrm{a}$ \\
$5,905 \mathrm{a}$ & $4,020 \mathrm{a}, \mathrm{b}$ \\
$5,965 \mathrm{a}$ & $4,010 \mathrm{a}, \mathrm{b}$ \\
$6,208 \mathrm{a}$ & $4,290 \mathrm{a}$ \\
$6,285 \mathrm{a}$ &
\end{tabular}

4,450 
Exchangeable $\mathrm{K}$ increased with increasing levels of slops, from $46 \mathrm{~kg} /$ ha when none was applied to $161 \mathrm{~kg} / \mathrm{ha}$ when the highest level was applied, whereas $\mathrm{HNO}_{3}$-soluble $\mathrm{K}$ increased from $267 \mathrm{~kg} / \mathrm{ha}$ when none was applied to $538 \mathrm{~kg} / \mathrm{ha}$ when the highest level was applied.

At the optimum level of slops ( $240 \mathrm{hl} /$ ha weekly for 12 weeks), 288,000 $\mathrm{L}$ would be applied per crop and the slops would contain $235 \mathrm{~kg}$ of $\mathrm{N}$ and 475 of $\mathrm{K} / \mathrm{ha}$.

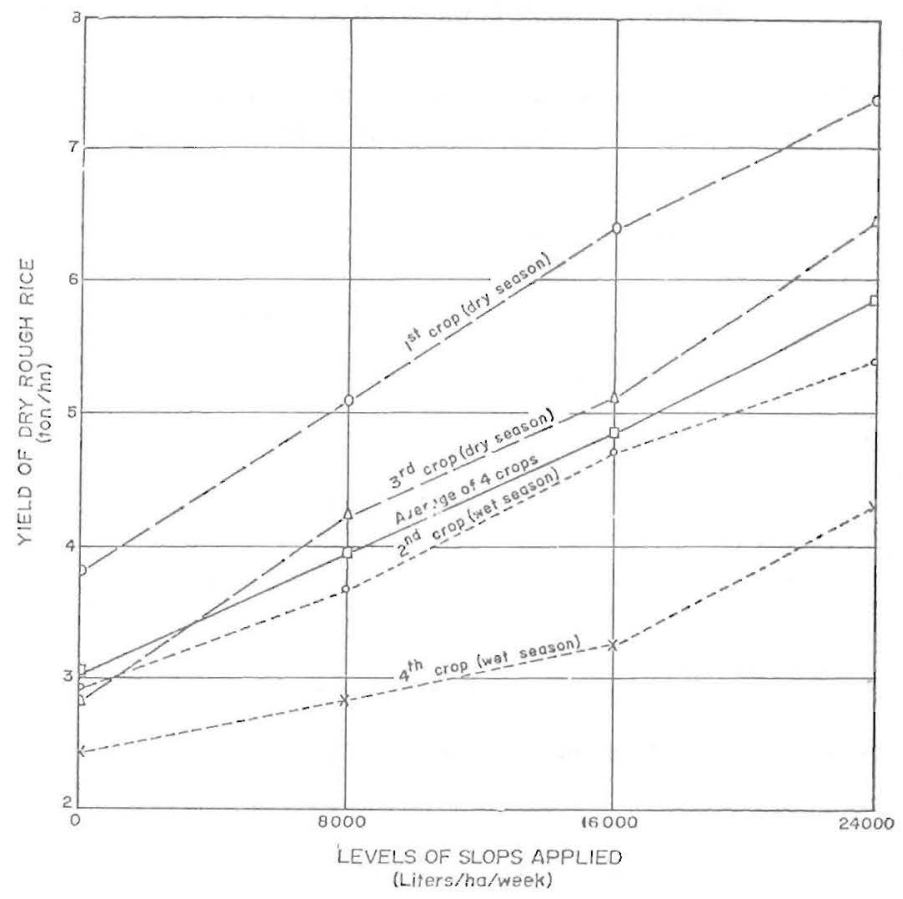

FIG. 1.-Effect of levels of slops applied on yields of four successive rice crops receiving no nitrogen or potassium fertilizer.

On the basis of the data obtained by Silva and Vicente-Chandler (6) under conditions similar to those in these experiments, in these four crops a total of about $550 \mathrm{~kg}$ of N/ha was taken up by high yielding rice plants. Thus, with the highest level of slops, about $59 \%$ of the $936 \mathrm{~kg}$ of $\mathrm{N} /$ ha applied (table 3 ) was taken up by the rice plants. This level of $\mathrm{N}$ recovery by the rice plants was similar to that usually obtained under very good conditions.

Applications of slops to four successive rice crops had a strong residual effect on yields of a subsequently planted rice crop receiving no fertilizer 
or slops (table 1). Yields increased from 3,070 $\mathrm{kg}$ of rough rice/ha produced by plots which had previously received neither $\mathrm{N}$ nor slops, to $3,480,3,790$ and $4,560 \mathrm{~kg} / \mathrm{ha}$ from plot receiving 80,160 and $240 \mathrm{hl}$ of slops/ha weekly during the preceeding four crops, respectively. Fertilizer $\mathrm{N}$ had no significant residual effect on rice yields except at the $240 \mathrm{~kg} /$ ha rate.

Slops as applied in this experiment, therefore, appear to be an efficient source of $\mathrm{N}$, which is apparently available gradually and at a rather uniform rate throughout the cropping period and, after several crops, beyond this period.

At the highest level of slops, 2,068 $\mathrm{kg}$ of $\mathrm{K} / \mathrm{ha}$ was applied, of which 386 accumulated in the soil as exchangeable or $\mathrm{HNO}_{3}=$ soluble $\mathrm{K}$ (table

TABLE 2.-Effect of levels of distillery slops and nitrogen fertilization on leaf composition of rice at the preblooming stage

\begin{tabular}{|c|c|c|c|c|c|}
\hline \multirow{2}{*}{ Treatment } & \multicolumn{5}{|c|}{ Dry weight composition of leaves (\%) } \\
\hline & $\mathrm{N}$ & $\mathrm{P}$ & $\mathrm{K}$ & $\mathrm{Ca}$ & $\mathrm{Mg}$ \\
\hline No N, K or slops & 2.43 & .22 & 1.52 & .39 & .27 \\
\hline $\begin{array}{l}60 \mathrm{~kg} \text { of } \mathrm{N} \text { and } \mathrm{K} / \mathrm{ha} \text { at planting and } 45 \\
\text { days later }\end{array}$ & 2.12 & .23 & 1.62 & .36 & .24 \\
\hline $80 \mathrm{hl}$ of slops/ha weekly ${ }^{1}$ & 2.52 & .23 & 1.66 & .38 & .23 \\
\hline $160 \mathrm{hl}$ of slops/ha weekly & 2.00 & .25 & 1.60 & .37 & .21 \\
\hline $240 \mathrm{hl}$ of slops/ha weekly & 2.07 & .25 & 1.69 & .37 & .21 \\
\hline $\begin{array}{l}160 \mathrm{hl} \text { of slops/ha weekly }+60 \mathrm{~kg} \text { of N/ } \\
\mathrm{ha}^{2}\end{array}$ & 2.41 & .24 & 1.62 & .37 & .23 \\
\hline $\begin{array}{l}160 \mathrm{hl} \text { of slops/ha weekly }+120 \mathrm{~kg} \text { of } \\
\mathrm{N} / \mathrm{ha}\end{array}$ & 2.32 & .24 & 1.58 & .38 & .20 \\
\hline $\begin{array}{l}160 \mathrm{hl} \text { of slops/ha weekly }+240 \mathrm{~kg} \text { of } \\
\mathrm{N} / \mathrm{ha}\end{array}$ & 2.45 & .22 & 1.56 & .35 & .23 \\
\hline
\end{tabular}

${ }^{1}$ For 12 weeks, starting 2 weeks after planting.

${ }^{2}$ All $\mathrm{N}$ applied in two equal applications, one at planting and one 6 weeks later.

3), about $750 \mathrm{~kg}$ was taken up by the crop, and the remainder was apparently leached into the soil below the depths sampled.

The quantities of salts applied in the levels of slops used in this experiment should not constitute a problem with flooded rice when irrigation water is low in salts. At the highest level of slops, $240 \mathrm{hl} / \mathrm{ha}$ weekly for 12 weeks for each of two crops, a total of about 4,000 kg of salts ( $\mathrm{K}, \mathrm{Mg}, \mathrm{Ca}, \mathrm{Na}$ ) would be applied/ha yearly. As noted, $\mathrm{pH}$ of the soil decreased with increasing levels of slops and only $386 \mathrm{~kg} / \mathrm{ha}$ of the $2,068 \mathrm{~kg} / \mathrm{ha}$ of $\mathrm{K}$ applied to the four rice crops accumulated in the soil.

The possible accumulation of organic matter in the soil would be considered a favorable aspect of slops applications. A total of about $50,000 \mathrm{~kg} / \mathrm{ha}$ of organic matter would be added to the soil yearly with 
TABLE 3.-Effect of levels of distillery slops and nitrogen fertilization on soil condition after four successive rice crops

\begin{tabular}{|c|c|c|c|c|c|c|c|c|c|}
\hline Treatment & $\mathrm{pH}$ & $\begin{array}{l}\text { Exchangeable } \\
\mathrm{Ca}\end{array}$ & $\begin{array}{l}\text { Exchangeable } \\
\mathrm{Mg}\end{array}$ & $\begin{array}{l}\text { Exchangeable } \\
\mathrm{NH}_{3}\end{array}$ & $\begin{array}{c}\text { Total } \\
\mathrm{N} \\
\text { applied }\end{array}$ & $\underset{\mathrm{K}}{\text { Exchangeable }}$ & $\begin{array}{l}\mathrm{HNO}_{3^{-}} \\
\text {soluble } \\
\mathrm{K}\end{array}$ & $\begin{array}{c}\text { Exchangeable } \\
+\mathrm{HNO}_{3} \\
\text { soluble } \\
\mathrm{K}\end{array}$ & $\begin{array}{c}\text { Total } \\
\mathrm{K} \\
\text { applied }\end{array}$ \\
\hline & & $m e / 100 \mathrm{~g}$ & $m e / 100 \mathrm{~g}$ & $\mathrm{~kg} / \mathrm{ha}$ & $\mathrm{kg} / \mathrm{ha}$ & $\mathrm{kg} / \mathrm{ha}$ & $\mathrm{kg} / \mathrm{ha}$ & $\mathrm{kg} / \mathrm{ha}$ & $\mathrm{kg} / \mathrm{ha}$ \\
\hline No N, K or slops & 7.15 & 11.0 & 11.5 & 234 & 0 & 46 & 267 & 313 & 0 \\
\hline $\begin{array}{l}60 \mathrm{~kg} \text { of } \mathrm{N} \text { and } \mathrm{K} / \mathrm{ha} \text { at planting } \\
\text { and } 45 \text { days later }\end{array}$ & 7.05 & 10.9 & 10.4 & 234 & 480 & 28 & 194 & 222 & 328 \\
\hline $80 \mathrm{hl}$ of slops/ha weekly ${ }^{1}$ & 6.95 & 10.5 & 11.2 & 184 & 312 & 77 & 339 & 416 & 688 \\
\hline $160 \mathrm{hl}$ of slops/ha weekly & 6.75 & 10.0 & 9.1 & 230 & 624 & 110 & 473 & 583 & 1,376 \\
\hline $240 \mathrm{hl}$ of slops/ha weekly & 6.30 & 9.3 & 9.3 & 260 & 936 & 161 & 538 & 699 & 2,068 \\
\hline $\begin{array}{l}160 \mathrm{hl} \text { of slops/ha weekly }+60 \\
\mathrm{~kg} \text { of } \mathrm{N} / \mathrm{ha}^{2}\end{array}$ & 6.75 & 9.7 & 9.5 & 202 & 864 & 119 & 439 & 558 & 1,376 \\
\hline $\begin{array}{l}160 \mathrm{hl} \text { of slops/ha weekly }+120 \\
\mathrm{~kg} \text { of N/ha }\end{array}$ & 6.60 & 9.9 & 9.7 & 230 & 1,104 & 109 & 428 & 537 & 1,376 \\
\hline $\begin{array}{l}160 \mathrm{hl} \text { of slops/ha weekly }+240 \\
\mathrm{~kg} \text { of } \mathrm{N} / \mathrm{ha}\end{array}$ & 6.50 & 9.5 & 10.9 & 220 & 1,584 & 116 & 457 & 573 & 1,376 \\
\hline
\end{tabular}

${ }^{1} 75 \mathrm{~kg}$ of $\mathrm{N}$ and $165 \mathrm{~kg}$ of $\mathrm{K} / 1000 \mathrm{hl}$ of slops.

${ }^{2}$ In two equal applications, one at planting and one 45 days later. 
two crops at the maximum application rates. However, the slops produced by the largest distillery is treated to remove most of the organic matter but still retains almost all of the $\mathrm{N}$ and $\mathrm{K}$.

On the basis of the results of these experiments, two crops of rice yearly would require a total of about $5,760 \mathrm{hl}$ of slops/ha. Thus the 12 million hl of slops produced yearly by the north coast distilleries could supply all of the fertilizer required by 2,100 ha $(5,200$ acres $)$ of rice. If rum production were doubled, as is predicted over the next decade, slops could provide all of the $\mathrm{N}$ and $\mathrm{K}$ required by about 10,000 acres of rice.

When slops are used as the sole source of $\mathrm{N}$ and $\mathrm{K}$ for rice, they substitute for fertilizer valued at about $\$ 250 /$ ha $(\$ 100 /$ acre) yearly with two crops per year. Slops from the distillery located at Arecibo would have to be pumped only a few kilometers to the main irrigation canal for the Arecibo river lowland, but those from the San Juan distillery would have to be pumped about $25 \mathrm{~km}$ to the Toa Baja and Vega Baja area.

\section{RESUMEN}

La industria de ron de Puerto Rico produce alrededor de 16,000 millones de hectolitros de mosto (flema) al año, mayormente cerca de la región en que se está estableciendo la industria arrocera.

Se realizaron cuatro siembras consecutivas de arroz en las mismas parcelas para comparar el efecto de distintos niveles de mosto y de nitrógeno sobre la producción y composición foliar del arroz y en la condición del suelo.

La producción de arroz aumentó con cada incremento de mosto de un promedio de $3,033 \mathrm{~kg}$ de arroz seco en cáscara por hectárea cuando no se aplicó mosto a 5,905 kg/ha cuando se aplicaron $240 \mathrm{hl}$ de mosto por hectárea por semana y durante 12 semanas, empezando 2 semanas después de sembrarlo.

Esta cantidad de mosto contiene un total de $215 \mathrm{~kg}$ de nitrógeno y 475 $\mathrm{kg}$ de potasio por hectárea y cosecha.

La aplicación de nitrógeno en adición a 160 hectolitros de mosto por hectárea por semana no aumentó la producción sobre la obtenida mediante la aplicación de 240 hectolitros de mosto por hectárea y semana.

La aplicación de mosto no afectó el contenido en N, P, K, Ca y Mg de las hojas.

El pH del suelo disminuyó según se aumentó el nivel de mosto de 7.15 cuando no se aplicó mosto a 6.3 cuando se aplicaron $240 \mathrm{hl}$. de mosto por hectárea y semana. Los tratamientos no afectaron el contenido en amonio cambiable en el suelo.

Tanto el potasio cambiable en el suelo como el extraído con ácido nítrico aumentaron según aumentó la aplicación de mosto. Al finalizar las cuatro 
cosechas, el total de ambos aumentó de $313 \mathrm{~kg}$ de potasio por hectárea cuando no se aplicó mosto, a 699 kg/ha cuando se aplicaron 240 hectolitros de mosto por hectárea y semana. La cantidad de calcio y magnesio cambiable en el suelo no se afectó con la aplicación de mosto.

Estos datos señalan que el mosto es una buena fuente de nitrógeno y de potasio para la producción de arroz. El mosto que se produce actualmente en la costa norte es suficiente para suplir todo el nitrógeno y el potasio para 2,100 ha (5,208 cuerdas) de arroz que puede distribuirse en el agua de riego.

\section{LITERATURE CITED}

1. Cheng, K. L. and Bray, R. H. 1951. Determination of calcium and magnesium in soil and plant materials, Soil Sci. 72: 449-58.

2. Innes, R. E., 1951. The agricultural utilization of dunder, Inter. Sugar J., (53) 99-101.

3. McLean, E. O., 1965. Aluminum methods of soil analysis, Am. Soc. Agron., Agron. Series No, 994-6.

4. Pérez-Escolar, R. and Lugo-López, M. A., 1982. Potencial del Mosto como Abono para Forrajeras, Adelanto Científico \$99, Esta. Exp. Agric. Univ. P.R.

5. Rosado, E. and González, I. M., 1978. Literature review of molasses distillery slops and its utilization as fertilizer, Rum Pilot Plant Prog. Rep. Agric. Exp. Stn. Univ. P.R.

6. Silva, S. and Vicente-Chandler, J., 1983. Nitrogen uptake and growth of irrigated rice as affected by nitrogen rates, J. Agric. Univ. P.R. 68 (4): 387-94.

7. Takata, T., 1957. Effect of distillery waste from alcoholic fermentation of molasses on the growth of rice plants, Hakko Kyokaishi 15, 509-12. 